\title{
Process Simulation-Based Improvements to Maximize Naphtha Production in an Existing Gas Processing Plant ${ }^{1}$ Mejoramiento basado en la simulación de procesos para la maximización de nafta en una planta existente de tratamiento de gases ${ }^{2}$
}

\author{
Adriana Mesa Gómez ${ }^{3}$ \\ Manuel Valero Valdivieso ${ }^{4}$ \\ Manuel Figueredo Medina
}

doi:10.11144/Javeriana.jyu20-2.psim

How to cite this article:

A. Mesa Gómez, M. Valero Valdivieso, and M. Figueredo Medina, "Process simulation-based improvements to maximize naphtha production in an existing gas processing plant," Ing. Univ., vol. 20, no. 2, pp. 355-371, 2016. http://dx.doi. org/10.11144/Javeriana.iyu20-2.psim

\footnotetext{
${ }^{1}$ Received on: November 12 $2^{\text {th }}$, 2014. Accepted on: November 12, 2015 This paper is based on the research project Design and Optimization of the Chemical Process in an Existing Gas Plant to Improve Naphtha Production, which was developed as part of the Master's program in Design and Process Management specializing in Chemical Processes at La Sabana University, Bogota, Colombia.

${ }^{2}$ Fecha de recepción: 12 de noviembre de 2014. Fecha de aceptación: 12 de noviembre de 2015. Este artículo se deriva de un proyecto de investigación denominado Design and Optimization of the Chemical Process in an Existing Gas Plant to Improve Naphtha Production, desarrollado por el grupo de investigación Energía, Materiales y Ambiente (GEMA) de la Universidad de La Sabana, Chía, Colombia.

${ }^{3}$ Maestría en Diseño y Gestión de Procesos, Facultad de Ingeniería, Universidad de La Sabana, Chía, Colombia.

E-mail: adrianamego@unisabana.edu.co

${ }^{4}$ Programa de Ingeniería Química, Facultad de Ingeniería, Universidad de La Sabana, Chía, Colombia.

E-mail: manuel.valero@unisabana.edu.co

${ }^{5}$ Programa de Ingeniería Química, Facultad de Ingeniería, Universidad de La Sabana, Chía, Colombia.

E-mail: manuelfm@unisabana.edu.co
} 


\section{Abstract}

This study estimates the parameters for the proper operation of each one of the process stages (compression, cooling, and separation) in an existing gas processing plant, which processes 1.5 million standard cubic feet per day (MMSCFD). The study also proposes changes in some existing operational equipment to maximize the production of naphtha, which translates into an improved efficiency in each analyzed stage and an improved production rate of fuel gas, liquefied petroleum gas (LPG) and naphtha, which are current products of the plant. First, the gas plant was simulated using the Aspen HYSYS ${ }^{\circledR}$ V7.3 software with the current operational plant conditions and the measured properties of the fluids (gas chromatography for input gas, fuel gas, and LPG). Subsequently, unidimensional searches were performed via sensitivity analyses of the key stages of the process to obtain suitable parameters for improving naphtha production. This resulted in a maximum naphtha recovery rate of $99.13 \%$ (which is an improvement over the current recovery rate of $82.79 \%$ ) and an increase in naphtha quality of $20.85 \%$. The study allowed to have a sensibility analysis for nafta recovery, which provides a tool for decision-making and establishes a basis for analyzing other plants

\section{Keywords}

naphtha; simulation; Aspen HYSYS; Sensitivity analysis

\section{Resumen}

Este artículo busca determinar los intervalos de operación adecuados en diferentes etapas de proceso (compresión, enfriamiento y separación) de una planta de gas existente y diseñada para procesar 1.5 millones de pies cúbicos estándar por día (MMSCFD) de gas, así como modificar algunos equipos operacionales existentes en busca de maximizar la producción de nafta, lo cual significa una mayor eficiencia en cada etapa analizada y mayor rendimiento en la producción de fuel gas, gases licuados de petróleo (GLP) y nafta, que son los productos actuales de la planta. En primera instancia, se llevó a cabo la simulación del proceso según las condiciones operacionales actuales de la planta y las propiedades monitoreadas de los fluidos manejados (cromatografía de gases para el gas de entrada, fuel gas y GLP). Este procedimiento se llevó a cabo con el software de simulación Aspen HYSYS ${ }^{\circledR}$ V7.3. Posteriormente, se llevaron a cabo búsquedas unidimensionales mediante casos de sensibilidad en las etapas clave del proceso y con esto se obtuvieron parámetros adecuados en cada etapa que permiten mejorar la producción de nafta. Con los resultados obtenidos se logró realizar una sensibilidad para maximizar la recuperación de nafta, lo que brinda una herramienta en toma de decisiones y propone bases de análisis para su utilización en otras plantas.

\section{Palabras clave}

nafta; simulación; Aspen HYSYS; análisis de sensibilidad 


\section{Introduction}

Naphtha is a petroleum product that can be extracted from oil or natural gas reservoirs. It is mainly composed of a mixture of hydrocarbons, including ethane, propane, butane, and heavy hydrocarbons [1]. It is the most important raw material for the production of ethylene [2] and it is used for manufacturing high-octane gasoline [3], [4].

Several studies have explored different methods to separate naphtha from natural gas efficiently. Options such as the use of Joule-Thompson expansion valves, turbo expansion, and propane-driven cooling have been studied individually, but Manning et al. [5] stated that the combination of the three is generally used to improve the process efficiency. The cooling process is perhaps most commonly used in the design of chemical processes that use condensation to separate a liquid phase of heavy hydrocarbons from a gas phase of light hydrocarbons. For this reason, detailed studies have been performed in which some of the cooling stage conditions were varied, decreasing energy consumption by $15.5 \%$ and increasing ethane recovery by more than $1.45 \%$ [6]. Previous studies on naphtha recovery from combustible oils mixed with a gas phase have reported recoveries of up to $62.6 \%$ via electrical cooling processes and $96.8 \%$ using energy from cryogenic liquefied natural gas [1]. It is worth noting that, despite obtaining high yields, several stages of the latter process are highly irreversible [7], which translates into considerable energetic losses. However, a more recent study involving naphtha recovery from liquefied natural gas reported efficiencies above $93.3 \%$ by adding an additional cooling stage to the conventional process [8]. In this case, the energy consumption was still high, which suggests that the energy necessary to recover naphtha with liquefied gas is directly proportional to the process efficiency. Finally, the technological-economic analysis of a potential process for naphtha recovery that changed the composition of the raw material concluded that raw materials that are richer in heavy hydrocarbons require more cooling than lean raw materials, leading to a greater energetic requirement [9]. 
Simulation has been used as a tool to analyze different operating conditions at different gas processing plants. Al-Sobhi and Elkamel [10] carried out a simulation of a gas processing network process using Aspen Plus V7.3. They also developed an optimization model to maximize profits of the gas processing network, being restricted to the overall material balance and the capacity of the plant, the available raw material and market demand. Rahimpour et al. [11] used a steady-state flowsheet simulator to find the main effective parameters and their influence on a natural gas dehydration unit. They also used sensitivity analysis to find optimal operating conditions of the dehydration unit. There have also been efforts in using a simulator to make process conceptual designs. Ferro et al. [12] developed three different configurations for an aromatic-aliphatic separation from low aromatic content naphtha. They also made use of sensitivity analysis to find better conditions to improve the purity of aromatic products.

The studied gas plant currently uses 1.5 million standard cubic feet per day (MMSCFD) of natural gas as a feedstock and produces 0.750 MMSCFD of fuel gas (the principal product for electric generation), 110 barrels per day (BPD) of liquefied petroleum gas (LPG), and 40 BPD of naphtha as byproducts. The operating company hopes to commercialize the generated naphtha; thus, it has a great interest in maximizing its production so that most of the naphtha in the natural gas can be recovered.

In the current gas processing plant, liquid hydrocarbons are separated from the gas through a propane-driven cooling process that decreases the flow temperature down to $10{ }^{\circ} \mathrm{F}$, which promotes condensation of the substances after reaching their dew points. However, new procedures to recover natural gas liquids (NGLs), including lean oil absorption, solid bed absorption, pressure-driven membrane separation, and supersonic separation processes have been studied [13]. The purpose of this study was to evaluate the initial, intermediate, and final stages of the operational process of the gas plant to determine the appropriate operating parameters and infrastructure changes that are necessary to maximize naphtha production. This evaluation was performed using sensitivity analyses of the compression, cooling, and separation stages, which identified the required operational and infrastructure changes in each stage of the process. The process simulation and sensitivity analysis were performed using the Aspen HYSYS ${ }^{\circledR}$ V7.3 software. 


\section{Methodology}

The general methodology for this work is shown in Figure 1.

Figure 1. General methodology

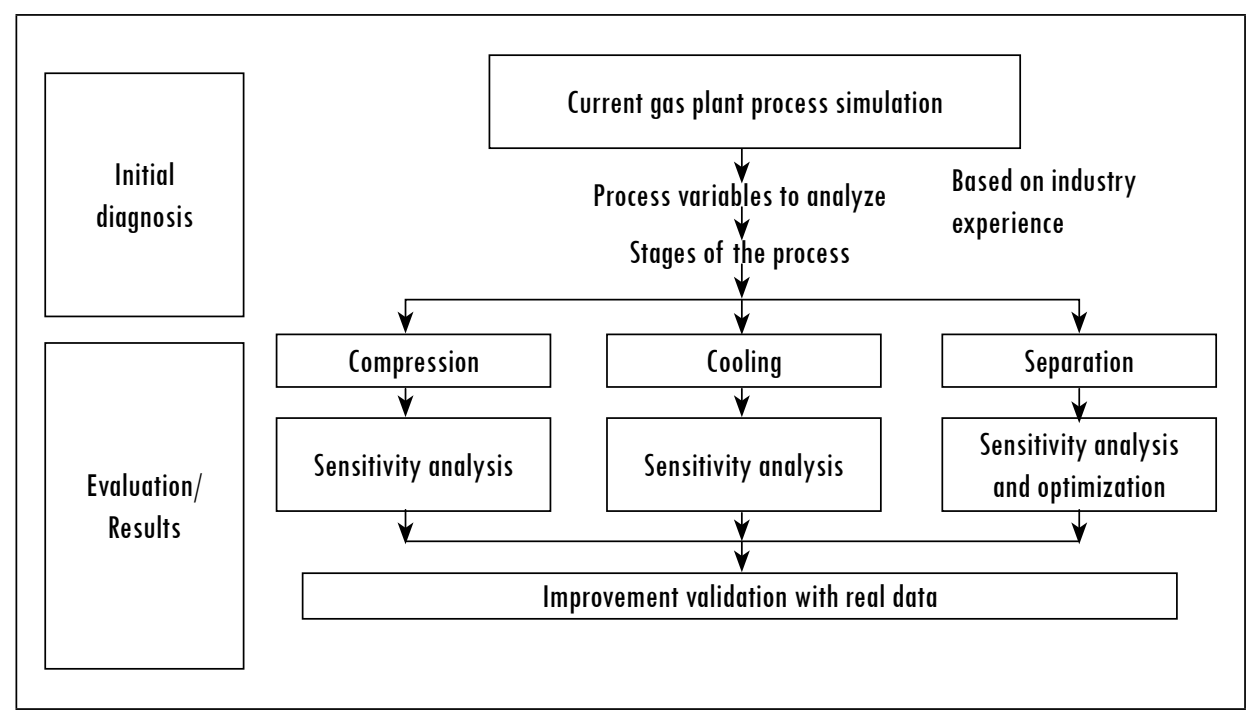

Source: authors' own creation

\section{Process Simulation and Validation}

The process simulation was performed using the Peng-Robinson thermodynamic model considering involved real and nonpolar chemical species [10], [11] and using real operational data from the gas plant. Design data for the equipment were requested, as well as the compositions of the feedstock, products, and byproducts, which were obtained from in-situ chromatography of the main process flows (input gas, fuel gas, and LPG). The water content was determined using the McKetta and Wehe correlation [5]. Figure 2 shows a block diagram of the chemical process performed in the gas plant, and Figure 3 shows a flowchart of the simulated process in Aspen HYSYS.

Process capability indexes, which are defined as the product ratios in the Fuel Gas $\left(\mathrm{H}_{2}+\mathrm{H}_{2} \mathrm{~S}+\mathrm{CO}_{2}+\mathrm{N}_{2}+\mathrm{C}_{1}+\mathrm{C}_{2}\right)$, LPG $\left(\mathrm{C}_{3}+\mathrm{iC}_{4}+\mathrm{nC}_{4}\right)$, and naphtha $\left(\mathrm{iC}_{5}+\mathrm{nC}_{5}+\mathrm{C}_{6}+\mathrm{C}_{7+}+\mathrm{C}_{10+}+\mathrm{C}_{12+}\right.$ ) flows, and their respective yields, were used to validate the results of the process simulation. Table 1 shows the output values from the simulations and compares them with the empirical values that were recorded during plant operation. 
Figure 2. Block diagram of the analyzed gas plant

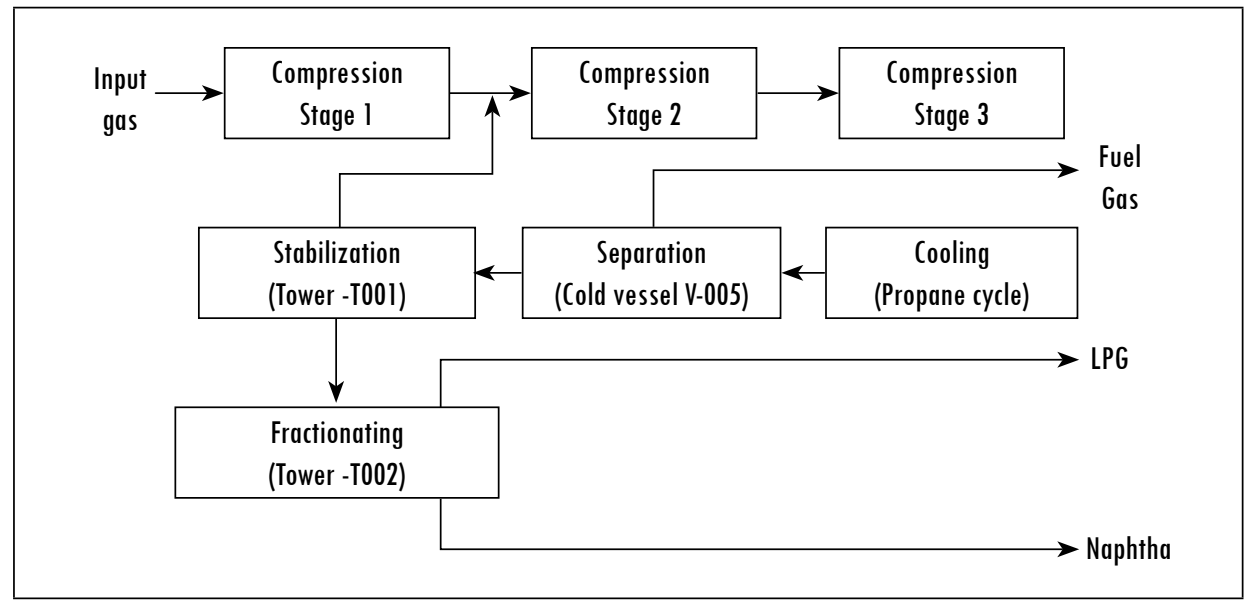

Source: authors' own elaboration

Figure 3. Flowchart of the current gas plant process simulated in Aspen HYSYS ${ }^{\circledR}$

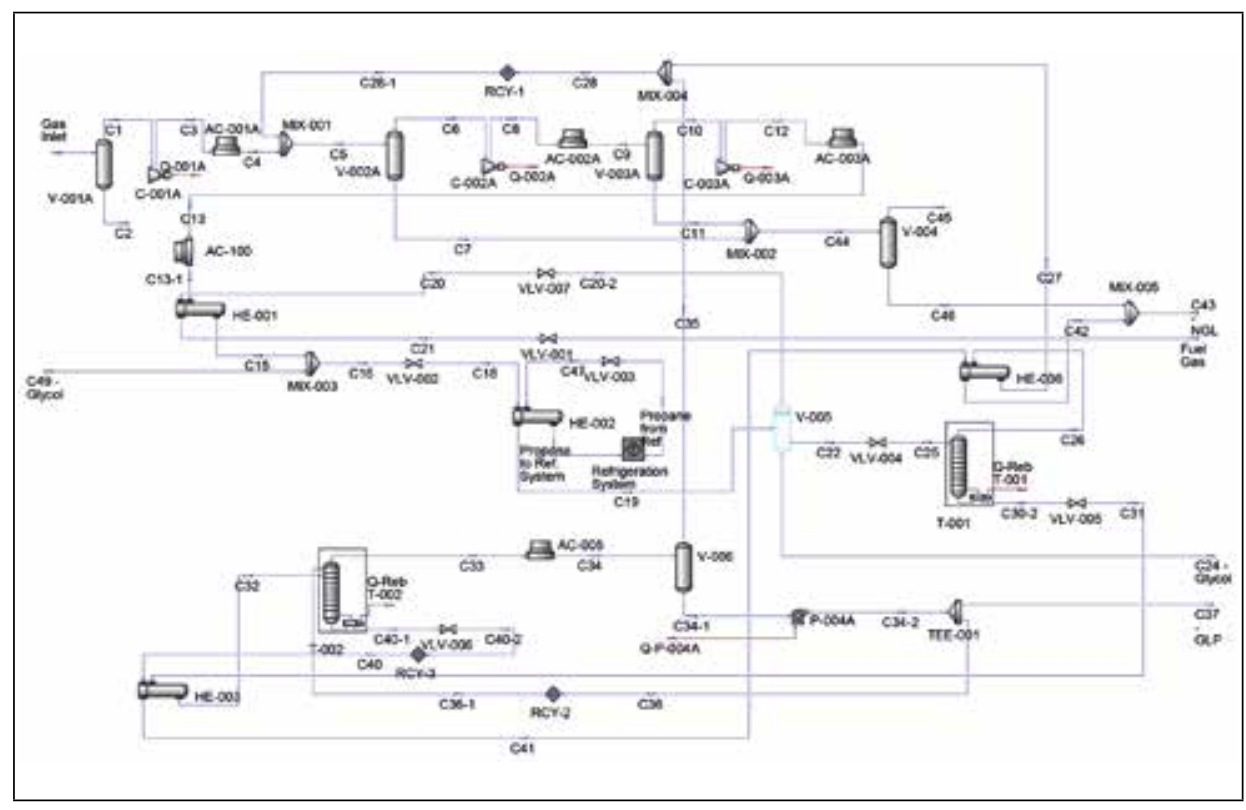

Source: Aspen HYSYS Simulation Software 
Table 1. Output flow conditions with current operating conditions

\begin{tabular}{|l|c|c|c|c|c|c|}
\hline \multirow{2}{*}{ Properties } & \multicolumn{2}{c|}{ Fuel gas } & \multicolumn{2}{c|}{ LPG } & \multicolumn{2}{c|}{ Naphtha } \\
\cline { 2 - 7 } & Real & Simulation & Real & Simulation & Real & Simulation \\
\hline Mass flow $\left(\mathrm{lb}^{*} \mathrm{~h}^{-1}\right)$ & - & 2049 & - & 1135 & - & 412.7 \\
\hline Liquid flow (BPD) & - & - & 119 & 144.9 & 40 & 42.06 \\
\hline Gas flow (MMSCFD) & 0.75 & 0.8259 & - & - & - & - \\
\hline Temperature $\left({ }^{\circ} \mathrm{F}\right)$ & 70 & 74.1 & - & 124.6 & - & 79.9 \\
\hline Pressure $(\mathrm{psig})$ & 78 & 78 & 155 & 180 & - & 91 \\
\hline
\end{tabular}

(-): Property not measured or not available

Source: authors' own elaboration

The simulation parameters were based on the current operating values; however, noticeable differences in the volumetric flow rates of the fuel gas and LPG are present. Thus, percent error values for each flow were obtained as follows:

$$
\% \text { Error }=\frac{\mid \text { Value }_{\text {real }}-\text { Value }_{\text {simulated }} \mid}{\text { Value }_{\text {real }}} * 100
$$

$\%$ Error Fuel Gas $=9.85 \%$

$\%$ Error LPG $=21.18 \%$

$\%$ Error Naphtha $=3.13 \%$

A mass reconciliation was made in the plant to find the discrepancies between simulated and real values to explain the errors found. Table 2 gives the real compositions and their comparison with the simulated values. In the Fuel Gas stream, the higher difference is in Propane, showing $8.33 \mathrm{~mol} \%$ instead of $4.31 \mathrm{~mol} \%$, giving a difference of $5.09 \mathrm{lbmol} / \mathrm{h}$ of additional Propane. The real LPG stream shows a lack of Propane ( $45.15 \mathrm{~mol} \%$ in contrast with $60.62 \mathrm{~mol} \%$ ) and an excess of i-Pentane $(6.67 \mathrm{~mol} \%$ vs.. $2.52 \mathrm{~mol} \%)$ and n-Pentane $(5.77$ mol \% vs. $1.11 \mathrm{~mol} \%)$. For the LPG stream, the molar differences were 5.56 $\mathrm{lbmol} / \mathrm{h}$ less propanol and an excess of $0.8113 \mathrm{lbmol} / \mathrm{h}$ and $0.6552 \mathrm{lbmol} / \mathrm{h}$ of $\mathrm{n}$-Pentane and i-Pentane respectively. These values support the errors between Fuel Gas and LPG shown before. Additional sources of error can be explained by possible mass losses during plant operation and the occasional gas discharges to the torch due to overpressure. 
Table 2. Comparison of real vs. simulated compositions

\begin{tabular}{|c|c|c|c|c|c|}
\hline & \multirow{3}{*}{ Compound } & \multicolumn{2}{|c|}{ Fuel Gas } & \multicolumn{2}{|c|}{ LPG } \\
\hline & & \multirow{2}{*}{$\begin{array}{c}\text { Real } \\
\text { mol\% } \%\end{array}$} & \multirow{2}{*}{$\begin{array}{c}\text { Simulation } \\
\mathrm{mol} \%\end{array}$} & \multirow{2}{*}{$\begin{array}{c}\text { Real } \\
\text { mol } \%\end{array}$} & \multirow{2}{*}{$\begin{array}{c}\text { Simulation } \\
\mathrm{mol} \%\end{array}$} \\
\hline & & & & & \\
\hline $\mathrm{H}_{2}$ & Hydrogen & 0.00 & 0.00 & 0.00 & 0.00 \\
\hline $\mathrm{H}_{2} \mathrm{~S}$ & Hydrogen Sulfide & 0.00 & 0.00 & 0.00 & 0.00 \\
\hline $\mathrm{CO}_{2}$ & Carbon Dioxide & 3.26 & 3.71 & 0.05 & 0.00 \\
\hline $\mathrm{N}_{2}$ & Nitrogen & 1.16 & 1.84 & 0.00 & 0.00 \\
\hline $\mathrm{C}_{1}$ & Methane & 61.54 & 62.87 & 0.00 & 0.00 \\
\hline $\mathrm{C}_{2}$ & Ethane & 23.70 & 26.49 & 5.80 & 1.76 \\
\hline $\mathrm{C}_{3}$ & Propane & 8.33 & 4.31 & 45.15 & 60.62 \\
\hline $\mathrm{iC}_{4}$ & i-Butane & 0.60 & 0.26 & 9.80 & 10.06 \\
\hline $\mathrm{nC}_{4}$ & n-Butane & 1.17 & 0.43 & 25.91 & 23.91 \\
\hline $\mathrm{iC}_{5}$ & i-Pentane & 0.15 & 0.05 & 6.67 & 2.52 \\
\hline $\mathrm{nC}_{5}$ & n-Pentane & 0.09 & 0.03 & 5.77 & 1.11 \\
\hline $\mathrm{C}_{6}$ & Hexanes & 0.00 & 0.01 & 0.85 & 0.02 \\
\hline $\mathrm{C}_{7+}$ & Heptanes plus & 0.00 & 0.00 & 0.00 & 0.00 \\
\hline $\mathrm{C}_{10}+$ & Decanes plus & 0.00 & 0.00 & 0.00 & 0.00 \\
\hline $\mathrm{C}_{12}+$ & Dodecanes plus & 0.00 & 0.00 & 0.00 & 0.00 \\
\hline $\mathrm{H}_{2} \mathrm{O}$ & Water & 0.00 & 0.00 & 0.00 & 0.00 \\
\hline
\end{tabular}

Source: authors' own elaboration

The calculated compositions of the products were compared to the reported compositions that were supplied by the gas plant for actual production (Table 2). A good representation of the Fuel Gas was obtained, particularly for methane and ethane. Similarly, a good approximation was obtained for the LPG; however, the simulation predicted a higher propane content. It was not possible to compare the simulation results with the real composition of naphtha because the gas plant does not have in-situ monitoring installed.

\section{Results and Discussion}

Each of the process stages were evaluated to determine their effect on naphtha recovery using simulations in the Aspen HYSYS ${ }^{\circledR}$ software. The selected variables for the analysis were those which have a higher impact based on the authors' industry experience. Simulation tools (like optimization and sensitivity 
analysis) were used to determine the production behavior (yield) of naphtha compared to the key operational conditions that influence its maximization. The evaluated process stages were the following:

- Compression (inlet pressure at the initial two-phase separator V-001).

- Cooling (starting up air cooler AC-004, which was offline).

- Cooling (inlet temperature to cold vessel V-005).

- Separation (reflux ratio in column T-002).

\subsection{Compression (Inlet Pressure at the Two-Phase Separator V-001)}

The impact of the inlet pressure on the naphtha recovery is shown in Figure $4 \mathrm{a}$. The lower the inlet gas pressure is, the higher the naphtha mass flow rate at the output (that is, the naphtha recovery is inversely proportional to the input gas pressure); thus, the recovery and yield percentage of this product increases from initial values of $76.7 \%$ recovery at 40 psig to $99.8 \%$ when the pressure is 0 psig. Moreover, LPG has low recovery sensitivity compared to the inlet gas pressure (varies from $87.9 \%$ recovery at 40 psig to $87.54 \%$ recovery at 0 psig) and is, thus, directly related to pressure variations. This demonstrates that pressure has a significant effect during the gas conditioning stage, where a certain amount of heavy hydrocarbons in the inlet gas are carried by the residues of V-001 (two-phase separator-gas conditioning reservoir). Nevertheless, the increase in the mass flow rate of naphtha is a result of the diminished water removal capability of the two-phase separator, which in turn increases the water content in the product. Figure $4 \mathrm{~b}$ shows that a lower pressure results in higher water content. This suggests that the addition of a device that is capable of properly separating NGLs and water will increase the amount of naphtha that is recovered in the process. The current two-phase separator is producing 37.23 BPD of naphtha. Changing it for a three-phase separator able to remove water from the residual flows in the compression stage would allow the recovery of an additional $1.5 \mathrm{BPD}$ of naphtha, completing a total production of $38.73 \mathrm{BPD}$ of naphtha.

As shown in Figure 4a, naphtha recovery is impacted by changes in the operating pressure, ranging from 5 to 40 psig, while LPG recovery is affected from 20 psig up to 40 psig. Figure 5 analyzes the pressure effect on the mass flow of the individual main component in naphtha and LGP streams. Figure 5 a shows how propane, n-butane, and i-butane are susceptible to changes in pressure above 20 psig. Changes in mass flow of heavier compounds in the naphtha stream are likely to change with pressure and the longer the chain, the more 
susceptible to pressure. $\mathrm{C} 7+*$ is the most sensitive compound to pressure, reducing its amount at the naphtha as the pressure grows up. This fact supports the idea to operate the three-phase separator at lower pressures.

Figure 4. a) Percent LPG and naphtha recovery vs. inlet gas pressure.

b) Mass fraction of water in the $\mathrm{V}$ - 101 outlets

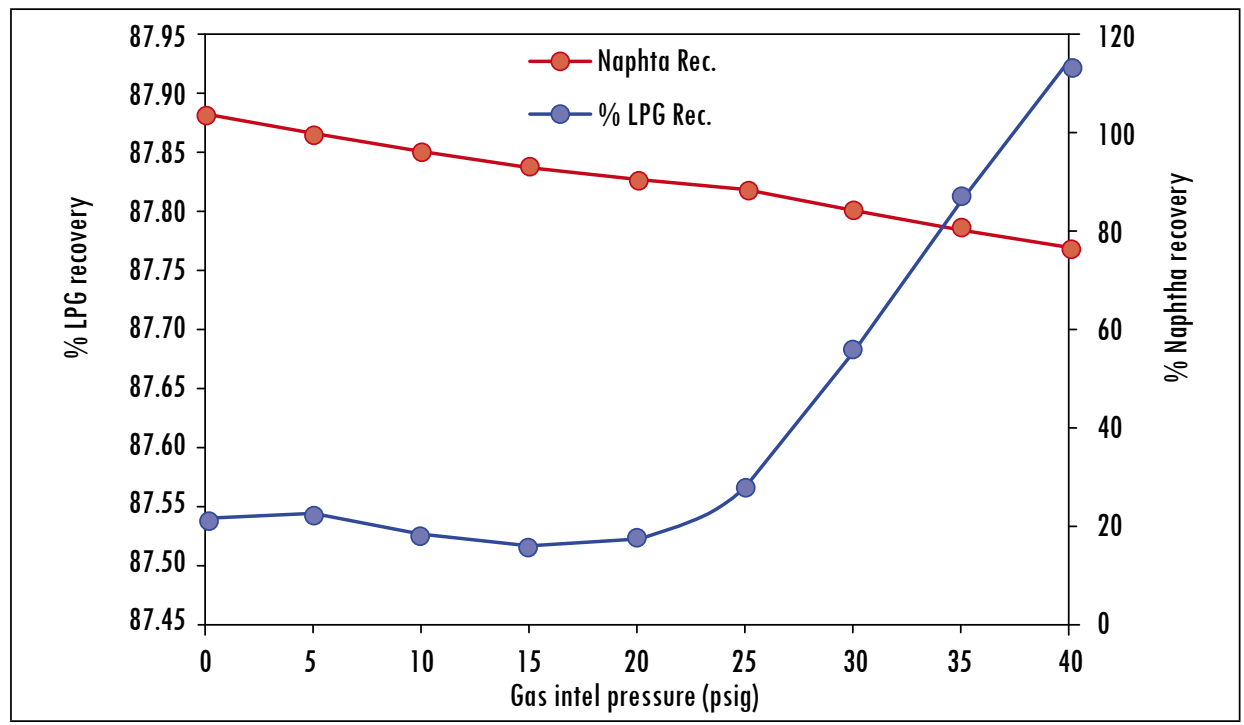

a)

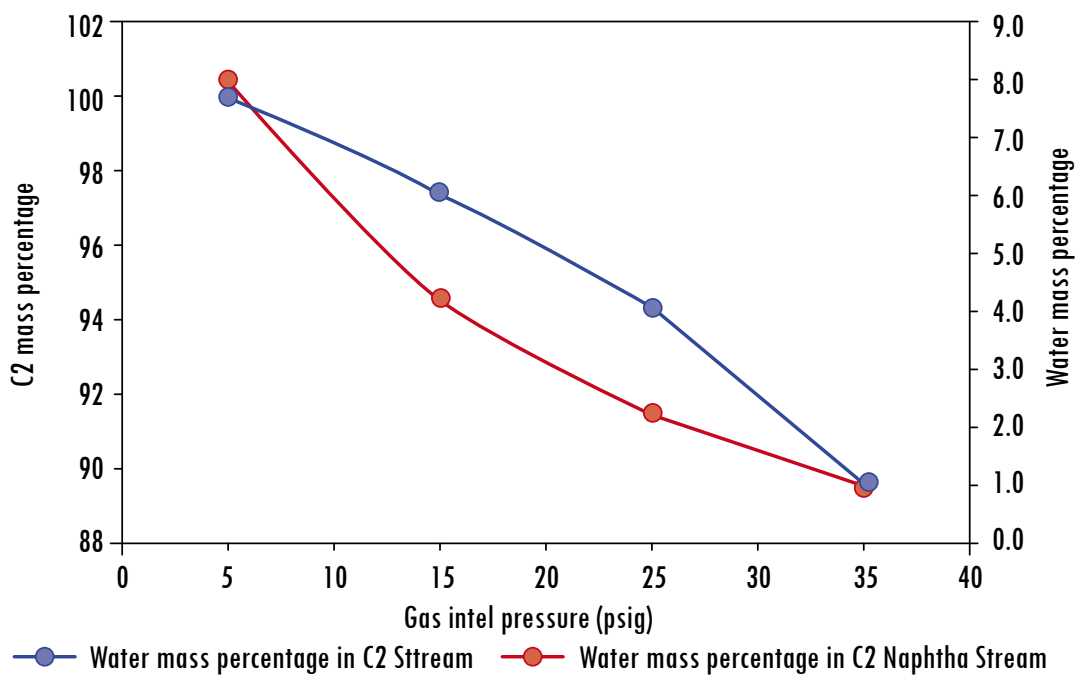

b)

Source: authors' own elaboration 
Figure 5. a) Component mass flow in LPG stream. b) Component Mass flow in Naphtha Stream

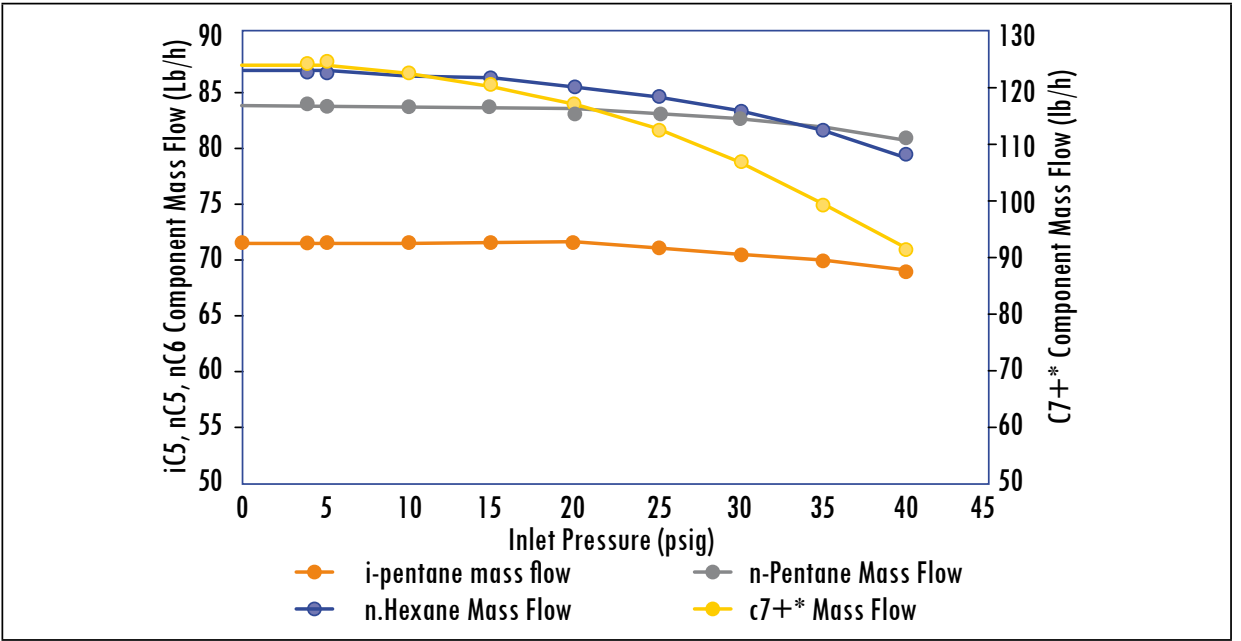

a)

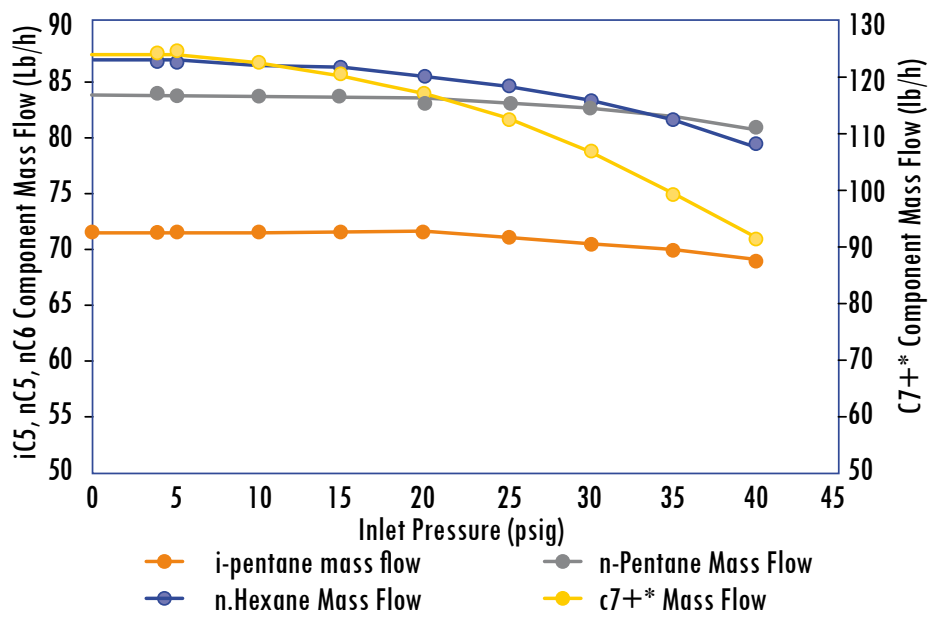

b)

Source: authors' own elaboration

\subsection{Cooling (Startup of Air Cooler AC-004)}

A simulation of the gas plant that considers the design specifications of the cooling stage was performed. The addition of air cooler AC-004 to the process (which is currently offline due to issues with the structural integrity of its tubing) allowed adequate inlet temperatures to be reached at cold vessel V-005 using a lower cooling demand in the refrigeration cycle. The results are analyzed in the 
next subsection. In summary, this modification did not increase the recovery rate of naphtha but it is necessary to achieve improved efficiency in the cooling process (propane cycle).

\subsection{Cooling (Inlet Temperature at Cold Vessel V-005)}

This parameter affects the separation efficiency of light compounds (fuel gas) in cold vessel V-005. Thus, a simulation from a temperature of $0^{\circ} \mathrm{F}$ (the operating temperature defined in the basic engineering details that were developed for the gas plant) up to $10^{\circ} \mathrm{F}$ (current operation) was performed to determine if a lower operating temperature can improve the hydrocarbon flow in the first separation stage. The results are shown in Table 3. Changes in both the inlet and operating temperatures of the V-005 separator do not have significant effects on naphtha production. However, the amount of produced fuel gas is inversely related to the amount of LPG produced, which suggests that temperature in this stage only affects the propane and butane.

Table 3. Process mass flow rates at several V-005 operating temperatures

\begin{tabular}{|c|c|c|c|c|c|c|c|c|}
\hline \multirow{2}{*}{\multicolumn{2}{|c|}{$\begin{array}{l}\text { Inlets } \\
\left(\mathrm{lb}^{*} \mathrm{~h}^{-1}\right)\end{array}$}} & \multirow{2}{*}{ Outputs } & $0^{\circ} \mathrm{F}$ & $2^{\circ} \mathrm{F}$ & $4^{\circ} \mathrm{F}$ & $6^{\circ} \mathrm{F}$ & $8^{\circ} \mathrm{F}$ & $10^{\circ} \mathrm{F}$ \\
\hline & & & \multicolumn{6}{|c|}{$\left(l b^{*} h^{-1}\right)$} \\
\hline Gas & 4027.4 & Fuel gas & 1992.2 & 2002.2 & 2013.2 & 2024.8 & 2036.8 & 2049.1 \\
\hline \multirow[t]{5}{*}{ Glycol } & 210.9 & LPG & 1194.7 & 1183.7 & 1172.5 & 1160.7 & 1148.3 & 1135.4 \\
\hline & & Naphtha & 414.0 & 414.2 & 413.5 & 412.6 & 412.4 & 412.7 \\
\hline & & Glycol & 230.0 & 230.8 & 231.4 & 232.0 & 231.8 & 231.3 \\
\hline & & $\mathrm{C}_{2}$ & 407.0 & 407.4 & 407.4 & 407.4 & 407.4 & 407.4 \\
\hline & & $\mathrm{C}_{45}$ & 0.0 & 0.0 & 0.3 & 0.9 & 1.6 & 2.4 \\
\hline Total & 4238.3 & Total & 4238.3 & 4238.3 & 4238.3 & 4238.3 & 4238.3 & 4238.3 \\
\hline
\end{tabular}

Source: authors' own elaboration

Nonetheless, applying the proposed operating changes in this process stage (cooling) requires the start-up of air cooler AC-004 and the operation of the cold vessel at $0{ }^{\circ} \mathrm{F}$ because these conditions improve the quality of the produced naphtha while reducing the LPG content and increasing the concentration of heavy hydrocarbons $\left(\mathrm{iC}_{5}+\mathrm{nC}_{5}+\mathrm{C} 6+\mathrm{C}_{7+}+\mathrm{C}_{10+}+\mathrm{C}_{12+}\right)$. These modifications to the gas plant would result in the recovery of an additional $0.71 \mathrm{BPD}$ of naphtha. 


\subsection{Separation (Reflux Ratio in Column T-002)}

The reflux ratio of fractionating tower T-002 was varied from 0.05 to 0.95 because it can operate over this hydraulic interval. Figure 6 shows that the recovery rate of naphtha increases, while the reflux ratio of the column decreases. In addition, the maximum reflux condition was demonstrated to not affect the quality of the produced naphtha due to the flow of compounds such as iC4 and $\mathrm{nC} 4$. Interestingly, the most sensitive equipment for naphtha recovery is the T-002 tower, which is the stage in which the LPG is separated. This equipment was simulated assuming a 1 inch metallic Pall Ring packing and a height equivalent to a theoretical plate (HETP) of $1.5 \mathrm{ft}$ as described in the technical specifications of the equipment. Substituting this packing with a higher efficiency packing $(\mathrm{HETP}=1 \mathrm{ft}$ ) would improve the naphtha separation and recovery (approximately 3 to $4 \mathrm{BPD}$ ).

An optimization model was developed to find the optimal reflux ratio in T-002 tower, which allowed getting the maximum naphtha and LPG mass flow. The objective function of the optimization model was the sum of ethane, propane, $\mathrm{n}$-butane, and i-butane mass flow in the naphtha stream plus the sum of $\mathrm{i}$-pentane, $\mathrm{n}$-pentane, $\mathrm{n}$ hexane, $\mathrm{C} 7+*, \mathrm{C} 10+*$, and $\mathrm{C} 12+*$ in the $\mathrm{LPG}$ stream.

The mass flow of each component in the feed of T-002 tower allows us to establish a maximum recovery interval of naphtha and LGP in top and bottom streams, respectively. In that sense, for a total mass flow of $1433.96 \mathrm{lb} / \mathrm{h}$ at T-002 inlet, the maximum naphtha recovery that could be achieved is 347.55 $\mathrm{lb} / \mathrm{h}$ and the maximum LGP recovery is $1086.41 \mathrm{lb} / \mathrm{h}$. On the other side, the upper limit of the reflux ratio interval (0.95) gives the minimum flow at the outlet streams. For these conditions, the minimum naphtha recovery is 229.66 $\mathrm{lb} / \mathrm{h}$ and the minimum LGP recovery is $1073.49 \mathrm{lb} / \mathrm{h}$.

Equations (5), (6), (7), and (8) shows the optimization model implemented in Aspen Hysys V7.3:

$$
\text { Min } Z=\text { Naphtha }{ }_{C 2+C 3 * i C 4}+L P G_{i C 5+n C 5+C 6+C 7 *+C 10 *+C 12 *}
$$

Reflux Ratio constraint: $0.05 \leq(1-\mathrm{R}) \leq 1$

LPG flow constraint: $0.7 \leq \frac{L P G}{F E E D} \leq 0.8$

Naphtha flow constraint: $0.1 \leq \frac{\text { Naphtha }}{\text { FEED }} \leq 0.8$ 
This model is a Non Linear Programming problem (NLP) and it was resolved using the Sequential Quadratic Problem (SQP) algorithm. The optimal reflux ratio was found at 0.0404 , giving a maximum naphtha flow of $3.40 \mathrm{lb} / \mathrm{h}$ and a maximum LPG flow of $32.06 \mathrm{lb} / \mathrm{h}$. At these conditions, the fractions of light components and water are $7.94 \%$ and $15.46 \%$ respectively, resulting in a higher naphtha composition $(76.6 \%)$. The total naphtha production was also optimized. At this point there is still a high water composition in the naphtha. The V-004 two-phase separator must be replaced with a horizontal three-phase separator to reach a further purification of naphtha. Once this separator was designed and incorporated in the simulation, the water content in the naphtha stream was reduced to $0.02 \%$ molar.

In summary, substituting the current packing with a more efficient one, changing the reflux ratio of the tower, and replacing the actual V-004 with a three-phase separator, the current operation of the separation stage went from 37.23 BPD to 42.14 BPD of naphtha, getting an additional naphtha production of 4.91 BPD.

Figure 6. Percent LPG and naphtha recovery as function of the reflux ratio in T-002

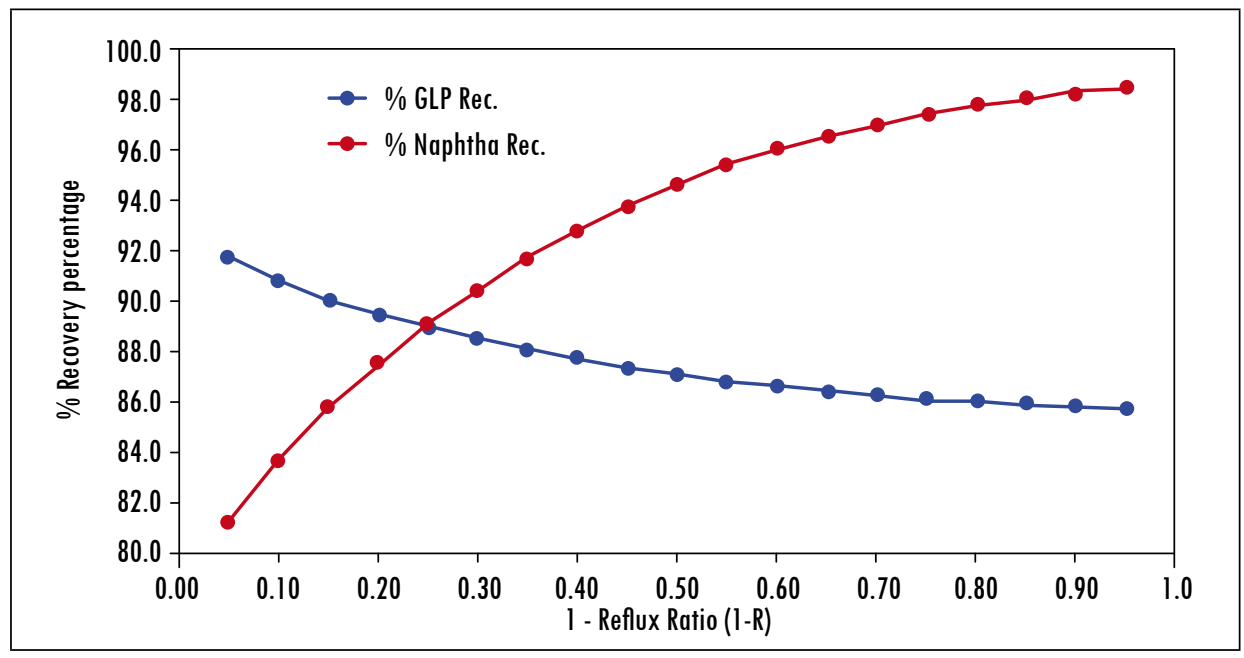

Source: authors' own elaboration

\section{Conclusions}

The results of the evaluation of the process stages helped to determine which stage is most ideal for improved naphtha production. As observed in Figure 7 , the naphtha recovery is more sensitive to changes in the separation stage, where 
92.92\% molar naphtha was recovered from the input gas flow. This is because a lower reflux ratio in the T-002 column induces a higher concentration of heavy hydrocarbons $\left(\mathrm{iC}_{5}+\mathrm{nC}_{5}+\mathrm{C} 6+\mathrm{C}_{7+}+\mathrm{C}_{10+}+\mathrm{C}_{12+}\right)$ in the naphtha flow. On the other hand, the less susceptible stage for naphtha recovery is the cooling stage because it was designed to condense the largest possible amount of heavy hydrocarbons in the input flow of cold vessel V-005.

Figure 7. Comparison of naphtha recovery percentages. The red line represents the current naphtha recovery in the gas plant

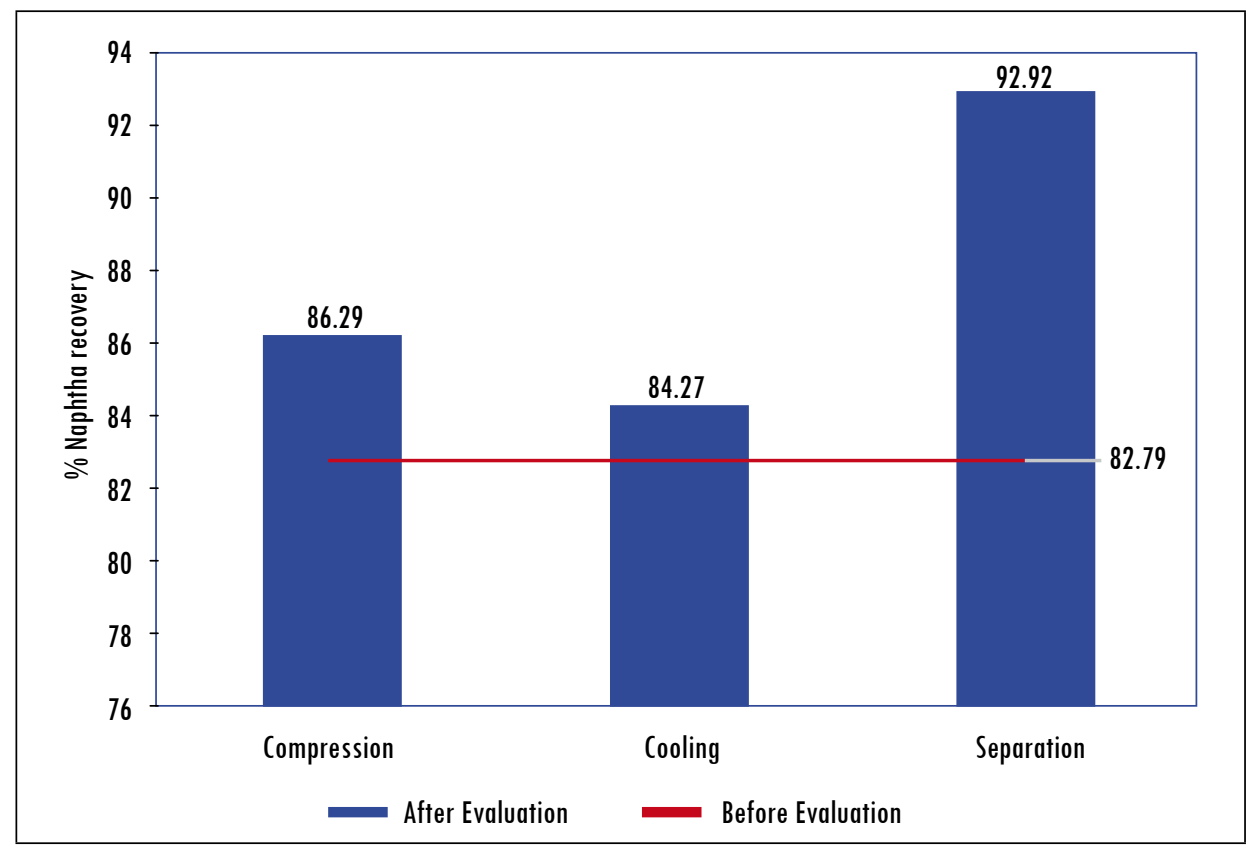

Source: authors' own elaboration

The sensitivity analysis of the gas plant allowed a comparison of its current performance (before the analysis) with the performance that could be obtained after process stabilization. Current plant operation under real conditions achieves naphtha recovery of up to $82.79 \%$ (red line in Figure 7); the proposed modifications to the compression stage will increase the recovery rate to $86.29 \%$. Moreover, by only modifying the cooling stage, the recovery rate will be enhanced to $84.27 \%$; if the separation stage is modified instead, the recovery percentage will reach $92.92 \%$ (Figure 7 ). 
Table 4 shows the volumetric flow rates in each stage of the process. The sum of the recovered volumetric flows of each stage suggests that the proposed operational and infrastructure modifications will lead to the recovery of an additional 7.12 BPD at the end of the process in the gas plant (compression, cooling, separation).

Table 4. Recovered volumetric flow of each process stage

\begin{tabular}{|l|c|c|c|}
\hline \multirow{2}{*}{ Stage } & Initial naphtha flow & Final naphtha flow & Increased naphtha flow \\
\cline { 2 - 4 } & BPD & BPD & BPD \\
\hline Compression & 37.23 & 38.73 & 1.5 \\
\hline Cooling & 37.23 & 37.94 & 0.71 \\
\hline Separation & 37.23 & 42.14 & 4.91 \\
\hline Total & & 7.12 \\
\hline
\end{tabular}

Source: authors' own elaboration

The results of a sensitivity analysis that was aimed at maximizing the recovery of naphtha showed that the process can be improved without interfering with the plant. The analysis provides a decision-making tool that can be implemented in other gas plants.

\section{References}

[1] H. Bian, W. Xu, X. Li, and Y. Quian, "A novel process for natural gas liquids recovery from oil field associated gas with liquefied natural gas cryogenic energy utilization." Chinese J. Chem. Eng., vol. 19, pp. 452-461, 2011.

[2] K. Keyvanloo, J. Towfighi, S. M. Sadrameli, and A. Mohamadalizadeh, "Investigating the effect of key factors, their interactions and optimization of naphtha steam cracking by statistical design of experiments." J. Anal. Appl. Pyrol., vol. 87, pp. 224-230, 2010.

[3] W. Hou, H. Su, Y. Hu, and J. Chu, "Modeling, simulation and optimization of a whole industrial catalytic naphtha reforming process on Aspen Plus platform." Chinese J. Chem. Eng., vol. 14, pp. 584-591, 2006.

[4] M. R. Rahimpour, D. Iranshahi, E. Pourazadi, and A. M. Bahampour, "Boosting the gasoline octane number in thermally coupled naphtha reforming heat exchanger reactor using de optimization technique." Fuel, vol. 97, pp. 109-118, 2012.

[5] F. S. Manning, and R. E. Thomson, Oilfield Processing, vol. 1 Natural Gas. Tulsa, Oklahoma: Pennwell Publishing Company, 1991.

[6] M. Mehrpooya, A Vatani, and S. M. Ali Mousavian, "Introducing a novel integrated NGL recovery process configuration (with a self-refrigeration system [open-closed cycle]) with 
minimum energy requirement." Chem. Eng. Process. Process Intensif., vol. 49, pp. 376-388, 2010 .

[7] B. Ghorbani, G. R. Salehi, H. Ghaemmaleki, M. Amidpour, and M. H. Hamedi, "Simulation and optimization of refrigeration cycle in NGL recovery plants with exergy-pinch analysis." J. Natural Gas Sci. Eng., vol. 7, pp. 35-43, 2012.

[8] A. Vatani, M. Mehrpooya, and B. Tirandazi, "A novel process configuration for coproduction of NGL and LNG with low energy requirement." Chem. Eng. Process. Process Intensif., vol. 63, pp. 16-24, 2013.

[9] M. Getu, S. Mahadzir, N. V. D. Long, and M. Lee, "Techno-economic analysis of potential natural gas liquid (NGL) recovery processes under variations of feed compositions." Chem. Eng. Res. Des., vol. 91, pp. 1272-1283, 2013.

[10] S. A. Al-Sobhi and A. Elkamel, "Simulation and optimization of natural gas processing and production network consisting of LNG, GTL, and methanol facilities." J. Natural Gas Sci. Eng., vol 23, pp. 500-508, 2015.

[11] M. R. Rahimpour, A. N. Rouzbahani, M. Bahmani, J. Shariat, and T. Tohidian, "Simulation, optimization, and sensitivity analysis of a natural gas dehydration unit." J. Natural Gas Sci. Eng., vol 21, pp. 159-169, 2014.

[12] V. R. Ferro, J. Paloram, J. De Riva, D. Moreno, and I. Diaz, "Aspen Plus supported conceptual design of the aromatic-aliphatic separation from low aromatic content naphtha using 4-methyl-N-butylpyridinium tetrafluoroborate ionic liquid." Fuel Process. Technol., vol 146, pp. 29-38, 2016.

[13] S. Mokhatab and W. A. Poe. "Chapter 10 - natural gas liquids recovery," in Handbook of Natural Gas Transmission and Processing, S. Mokhatab and W. A. Poe., Eds. $2^{\text {nd }}$ ed. Boston: Gulf Professional Publishing, 2012, pp. 353-391. 
